Journal of Business and Tourism

Volume 06 Number 01

January - June, 2020

\title{
The Emotional Intelligence of Project Manager and the Project Success
}

\author{
Dr. Aqsa Siddiq \\ Assistant Professor, QACC, University of Peshawar \\ aqsaqcc@uop.edu.pk \\ Muhammad Adeel \\ PhD Scholar, University of Peshawar \\ Ms. Sourath Qayyum Maher \\ sorathm@yahoo.com \\ Dr. Mujahid Hussain \\ Assistant Professor \\ National University of Computer and Emerging Sciences, Lahore \\ Mujahid.hussain@nu.edu.pk
}

\begin{abstract}
The massive failure of projects emphasizes the need to understand the factors that contribute to the project success. The projects of the construction sector in Pakistan also face difficulties of unachievable targets because of the lacking soft skills of the managers besides their technical competence. Therefore,this casual study is undertaken to check the influence of the project manager's emotional intelligence on the success of the project in the construction sector of Pakistan. A sample of 228 out of 250 project managers $(91 \%$ response rate) that work in those construction companies involved in construction projects responded, selected using convenient sampling technique. The data is analyzed using reliability study (Cronbach's Alpha), descriptive statistics, Skewness-Kurtosis, correlation, and regression analysis. The results of the study explain that the dimensions of emotional intelligence including self-awareness and self- regulation of project managers are showing positive and significant impact on the success of construction projects. While the key finding of the study is that social awareness has insignificant impact evident that managers normally give more focus on technical and hard skills of their teams than knowing and sensing others' feelings and perspective, and taking an active interest in their concerns. Construction industry and other project-based firms in Pakistan can take benefit from this research. Focusing on the significance of the emotional intelligence attributes and giving extensive trainings to the managers on soft skills can improve the ratio of the successful projects. The findings of the study strongly recommend soft skills training of the managers as well as the team. Further, a detailed investigation covering all the dimensions of emotional intelligence including empathy is directed for future studies.
\end{abstract}

Key Words: Emotional Intelligence, Project Success, Self-Awareness, Self-Regulation, Social- 
Awareness

\section{Introduction}

The globalization and growing industry have increased the number of projects in different areas including construction, information technology, security, and social sector (Yatim, Bredillet\& Ruiz, 2009).Organizations that use project management practices need to be more skilled to respond to risk or chances. Worldwide the investing budget on projects has largely increased which is now in billions (Anantatmula, 2008; Joseph\&Marnewick, 2018; Mullin, Smith \& McNamara, 2019). These increasing figures show the increasing demand of superior, rapid, and more cost-effective projects and with this increasing demand it is becoming difficult for project managers to manage the projects (Anantatmula, 2008). Literature is evident of failure of projects regardless of wellorganized and research-oriented project management (Cicmil\& Hodgson, 2006, Lee \& Xia 2005, Papke-shields et al., 2010). The vast number of projects failure emphasizes the need to understand the factors that contribute to the project success.

This increasing usage of project-based management system practices increases role of project managers. Researcher have widely discussed the project managers skills and capabilities needed to successfully completion of the project. As everyone is confronted by his or her own emotions and those of other people, various studies have depicted the worth and usage of emotional intelligence (EI) of managers in successful completion of projects (Crawford, 2007; Gehring, 2007; Oke, Aigbavboa, Ngcobo, \&Sepuru, 2017; Luong, Sivarajah \&Weerakkody, 2019). According to the finding of the studies, managers having high level of emotional intelligence tend to motivate and lead the employee in a better way resulted into project success. Moreover, emotional intelligence relatively a new approach which tends to forecast the project success and outcomes. However, the idea of emotional intelligence and its immediate connection with the success of the project is not greatly examined theme in Pakistani context.

It is observed that project in construction sector in Pakistan also face these difficulties of unachievable targets because of both emotional and technical skills therefore the current study is undertaken to check the influence of project manager's emotional intelligence on the success of the project in construction sector of Pakistan. Therefore, the current study is intended to find the relationship of emotional intelligence on the success of the project in construction industry, Peshawar, Pakistan. The main aim of the study is to check the impact of project managers' emotional intelligence on project success. However, the specific objectives of the study are:

1) Investigating the impact of self-awareness (emotional intelligence) on the success of the project in construction industry in Peshawar, Pakistan.

2) Investigating the impact of self-regulation on the success of the project in construction industry in Peshawar, Pakistan.

3) Investigating the impact of social awareness (emotional intelligence) on the success of the project in construction industry in Peshawar, Pakistan. 
This study will contributeto the existing literature on emotional intelligence and project success in the context of Pakistanadding significant value towards the current body of knowledge. The current model can be helpful for academic purpose to increase the knowledge of project managers about the importance of emotional intelligence and success of projects in the construction sector.

\section{Literature Review Emotional intelligence $($ EI)}

Salovey and Mayer (1990) were first who work on the emotional intelligence (EI) and defined it as aability of monitoring own and others feelings and emotions to guide in the thinking and actions.Emotional intelligence (EI) has been identified as one of the necessary managerial skills ever since this work came out. Studies highlighted how significant influence of manager's iteration has on the others, specifically in terms of complex projects(Joseph \& Newman, 2010; Clarke, 2010; Muller \& Turner, 2010). There has been evidence in the literature on the effectiveness of the emotional intelligence with the managerial effectiveness (O'Boyle et al., 2011). The literature has highlighted that "effective project management is not only done by the hard skills but there is role of the emotions regulation as well" (Fisher, 2011). Mazur at al. (2014) and Muller \& Turner (2007) highlighted the role of the emotional intelligence (EI) of managers in context of the project management and particularly these researches has highlighted that the ability of project's manager to understand and regulate their emotions in oneself and other helps them to achieve high quality results along with effective relationship with different stakeholders.

Self-Awareness: as a dimension of emotional intelligence is to understand and value one's own emotions (Siddiq, Baloch, Nadeem, Ahmad, \&Jan, 2015). In construction projects, the mangers must have self-awareness so that he can easily identify their own emotions and able to aware of his workers emotionsfor enhancing performance (Blair et al., 2007). According to (Shahzad et al., 2010) self-awareness deals with the one's feelings and his/her performance on the work so that to identify his strengths and weaknesses.

Self-Regulation:dimension of emotional intelligence deals with the management of the emotions or governing one's values and emotions. It refers to the capability of keeping emotions under control and not showing the disturbing emotions (Siddiq et al., 2015). Rahim et al., (2002) concluded that in complex nature of projects where normally individuals deal with the stressful circumstances, strong management of emotions and strong self-belief lead them to overcome the stressful situations and find a way out from the problems.

Social-Awareness:refers to sensing others' feelings and perspective, and taking an active interest in their concerns. Knowing others' emotions and perception can help managers been empathetic to others (Boyatzis 1982;Siddiq et al., 2015) and to deal related issues. As indicated by (Boyatzis 1982), individual having the expertise of social mindfulness 
are equipped for perusing circumstance normally and keep away from biases in their work and this recognizes star entertainers to the normal one.As a result of numerous works, EI is considered as a critical success factor in different fields like construction projects. engineering, banking law, other sports and in academic fields (Song et al., 2010, Brackett et al., 2011, Landa et al., 2008). In the area of project management, El plays a vital and positive role, as projects are temporary in nature and have definite start and end dates, so project managers need a high level of El skills to cope with the different aspects of the project (Druskat et al., 2006; Rahim, \& Malik, 2010; Serrat,2017).

\section{Project Success}

Project success (PS) in the complex project has always been an issue because of their timeframe of completion and their size (Toor \&Ogrunlana, 2010: Wang \& Huang, 2006). The studies however defined the project success (PS) in context of the project management and has considered two important components necessary to define the project success which are success criteria and critical success factors (Muller \&Jugdev, 2012; Turner \&Zolin, 2012). Success factors usually focus on the objectives measures such as cost, quality and the timeframe for completion (Pinto \&Slevin, 1987) these objective measures have been criticized when used to define the project success (PS) of the complex projects due to use of overly simplistic constructs for the complex and bigger projects (Toor \&Ogrunlana, 2010). Jugdev\& Muller (2005) have argued that these objective measures fail to address the other broader factors such as strategic management in project and the behavioral skills. The commitment, coordination and ability of the project participants support winning project performance (Jha \&Lyer, 2007; Doloi et al, 2011). Teams of "low" and "high" performance showed variations in terms of communication, human resource, cost, scope, risk and quality management areas in favor of "high" levels of project success (Papke-Sheilds et al, 2010; Zhang, \& Fan, 2013).

\section{Emotional Intelligence (EI) and Project Success(PS)}

Emotional intelligence is the ability to recognize and control the emotions or feelings of one self and the emotions or feelings of people live or work around (Salovey \&Mayer, 1990; Goleman 1998).Rezvani, Chang, Wiewiora, Ashkanasy, Jordan, \&Zolin, (2016) in their study has discussed this relationship in detail and has found the positive relationship between emotional intelligence and project success. Direct relationship of emotional intelligence on construction projects was studied by Zhang and Fan, (2013). In Pakistani context, Rahimand Malik, (2010) conducted a study on emotional intelligence and found that emotional intelligence enhances the level of job satisfaction and that leads to better performance and make the projects successful. According to the researches of Shahzad, Sarmad, Abbas, \& Khan, (2011) and Akhtar, Rahman, \& Haleem, (2018), there is a direct relation among emotional intelligence \& employee performance in construction sector. Kulkarni. Janakiram, \& Kumar, (2009) concluded in a study in Indian context and proved that the influence of emotional intelligence on project managers and supervisors in their performances. Lidebaum\& Jordan (2014) highlighted that emotional experience 
of people changes with time depending on the work behaviors and work experiences. However, employee at the working environment having positive emotions can perform better (Mayer et al, 2008; Sy et al, 2006) whereas negative emotions give rise to frustration and decrease in performance (Fisher, 2003; Von Glinow et al, 2004). Project managers with high emotional intelligence have positive impact on the employee in the troubleshooting and providing solutions for the success of the project (Peslak, 2005; Mount, 2006; Clarke, 2010, Mazur et al, 2014; Muller \& Turner, 2010).Based on the reviewed literature a study gap found to investigate the impact of dimensions of emotional intelligence on the project success in the construction industry of Pakistan so that the findings help managers to overcome the problems associated with lack of emotional intelligences. The following hypotheses are developed for the study and can be seen in the theoretical model of the study (Fig.1).

$\mathrm{H}_{1}$. Self-Awareness (Emotional Intelligence) is positively related with the project success in the construction companies of Peshawar.

$\mathrm{H}_{2}$. Self-Regulation (Emotional Intelligence) is positively related with the project success in the construction companies of Peshawar.

H3. Social-Awareness (Emotional Intelligence) is positively related with the project success in the construction companies of Peshawar.

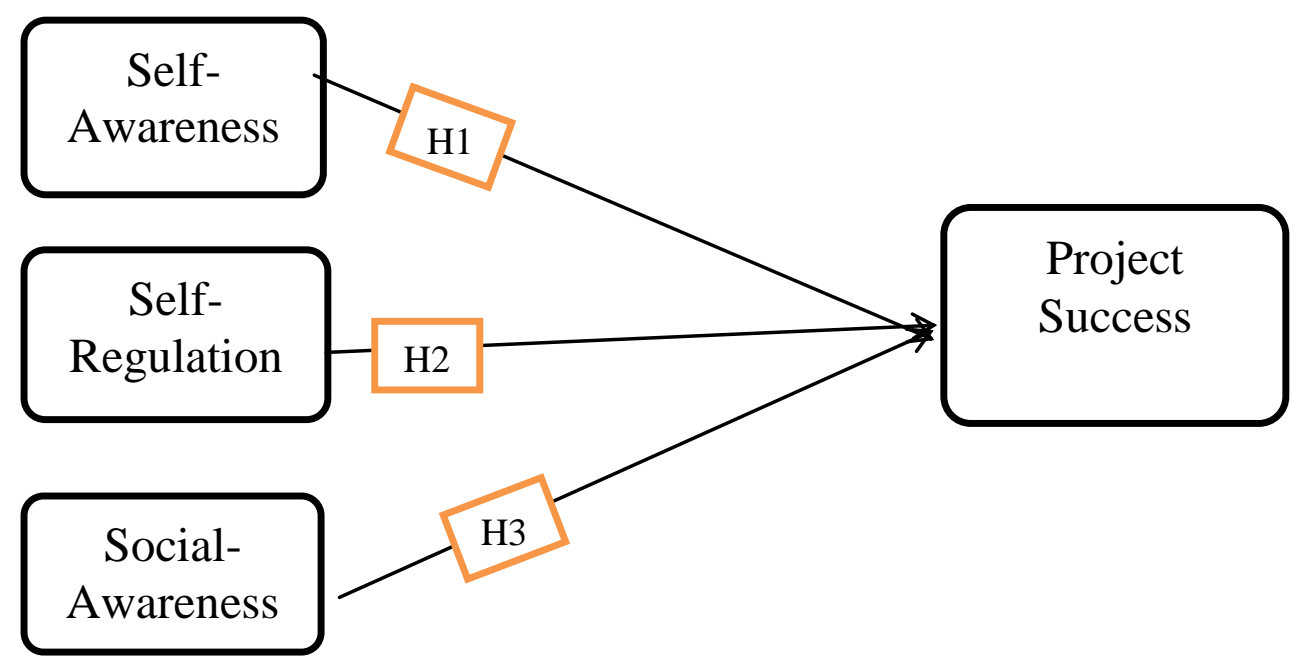

Emotional Intelligence (Independent Variable)

(Dependent Variable)

Fig 1. The theoretical framework of the study. Source: (Author Constructed)

\section{Methodology}

Study design:This casual study is conducted to investigate the role of factors of emotional intelligence in project success.Cross-sectional time horizon was used for the study due to the time constraint and limited resources. 
Population and Sample:The population of the study is the construction industry of Peshawar out of that a sample frame of 150 medium and large construction companies working in Peshawar is selected for the study.

Sample size and technique: The data is collected from a sample of 250 project managers that work in those construction companies involved in construction projects is selected. The convenience sampling technique is used, realizing the fact that not all the individuals in the sample would have an equal chance to be chosen.

Data collection instrument:Data is collected from the professionals of construction industry using adopted questionnaires (details given in Table 1) for the Emotional intelligence and Project Success as:

Table 1 :Details of the instruments used in the Study

\begin{tabular}{llll}
\hline Sr. & Variable & Source & Year \\
\hline 1 & Emotional Intelligence & Wong and Law & 2002 \\
2 & Project Success & Shenhar et al. & 2002 \\
\hline
\end{tabular}

Data analysis:For the analysis of collected data, a mix of statistical methods was employed including reliability study (Cronbach's Alpha), descriptive statistics, Skewness-Kurtosis, correlation, and regression analysis.

\section{Results and Discussion}

\section{Descriptive Analysis}

Table No.2 shows the mean values of all variable that are approximately same of descriptive analysis, the minimum value shows the minimum value of the variables and the maximum value shows the maximum value of the variables. This table elaborate that all values are from 1 to 5. It means statistical values are the mean values in actual about a specific variable. Standard deviation represents the deviance from the mean value of the data. Skewness and Kurtosis is the gauge to check the normality of the data. For the confirmation, the value of the Skewness must be between +1 to -1 and this table also elaborates that almost all values are in the defined ranges of skewness and confirmed the normality of the data. Kurtosis is measured to identify the normality of the data. This tables gives the rapidly idea of the idea and jarque-bera test is used to check the goodness of the data.

\section{Table 2: Descriptive Statistics}

\begin{tabular}{llllllll}
\hline & N & Mean & $\begin{array}{l}\text { Std. } \\
\text { Deviation }\end{array}$ & Skewness & \multicolumn{3}{c}{ Kurtosis } \\
& Statistic & Statistic & Statistic & Statistic & Std. Error Statistic & Std. Error \\
\hline Self-Awareness & 228 & 3.2719 & 0.96151 & -0.252 & 0.161 & -0.653 & 0.321 \\
Self-Regulation & 228 & 3.9489 & 0.88484 & -1.492 & 0.161 & 1.836 & 0.321 \\
Social Awareness & 228 & 3.0455 & 0.93691 & -0.494 & 0.161 & -0.499 & 0.321 \\
Project Success & 228 & 3.7639 & 0.73655 & -0.628 & 0.161 & 0.183 & 0.321 \\
\hline
\end{tabular}


Valid $N($ listwise $)=228$

\section{Reliability Analysis}

Reliability study is conducted on all variables using the Likert scale to measure the coordination influence from the scale of 1 to 5 . On the basis of the results obtained from reliability test (as in Table 3) explains the alpha coefficient value for the 5 items of EI (Self-Awareness) is 0.82 i.e. $82 \%$, for 5 items of self-regulation is 0.875 i.e. $88 \%$, for the 8 items of Social Awareness is 0.897 i.e. 90\%. and for the 6 items of project success is 0.709 i.e. $71 \%$.

Table 3: Reliability Analysis

\begin{tabular}{llll}
\hline Sr. No & Name of Variable & No of Items & Cronbach's Alpha \\
\hline 1 & EI (Self- Awareness) & 5 & $82 \%$ \\
2 & EI (Self-Regulation) & 5 & $88 \%$ \\
3. & EI (Social Awareness) & 8 & $90 \%$ \\
4 & Project Success & 6 & $71 \%$ \\
\hline
\end{tabular}

The alpha coefficient values for all the scales are greater than 0.6 suggesting a moderate and strong levels internal consistency among the items.

\section{Correlation}

Table No. 4 shows that correlation between EI (Self- Awareness), EI (Self- Regulation) , EI (Self- Regulation) and project success.

Table 4: Pearson Correlation Analysis of the Study $\quad$ (Sample $n=228$ )

\begin{tabular}{|c|c|c|c|c|c|c|}
\hline \multicolumn{7}{|c|}{ SoA } \\
\hline $\begin{array}{l}\text { Self } \\
\text { (SA) }\end{array}$ & Awareness & $\begin{array}{l}\text { "r" } \\
\text { Sig. (2-tailed) }\end{array}$ & 1 & - & & \\
\hline \multirow[t]{2}{*}{$\begin{array}{l}\text { Self } \\
(\mathrm{SR})\end{array}$} & Regulation & "r" & $0.176^{* *}$ & 1 & & \\
\hline & & Sig. (2-tailed) & 0.001 & & & \\
\hline \multirow{2}{*}{$\begin{array}{l}\text { Social } \\
\text { (SoA) }\end{array}$} & Awareness & "r" & $0.067 * *$ & $0.063 * *$ & 1 & \\
\hline & & Sig. (2-tailed) & 0.001 & 0.001 & & \\
\hline \multirow{2}{*}{\multicolumn{2}{|c|}{$\begin{array}{l}\text { Project Success } \\
\text { (PS) }\end{array}$}} & "r" & $0.505^{* *}$ & $0.807 * *$ & $0.195^{* *}$ & 1 \\
\hline & & Sig. (2-tailed) & 0.001 & 0.001 & 0.001 & \\
\hline
\end{tabular}

Significant at 0.01, two tailed

The Pearson correlation value $(\mathrm{r}=0.799, \mathrm{p}=0.000)$ between self-regulation $(\mathrm{SR})$ and Self Awareness (SA) explains a positively strong relationship. This explains the significance of link between the self-awareness and regulation in the same direction. The correlation value $(r=0.767, p=0.000)$ between social awareness (SoA) and self-awareness (SA) 
shows significantly positive and strong relationship. This implies that a manager having self-awareness can only feel the emotions and feelings of other at work and may be helpful to them. Similarly $r=0.591, \mathrm{p}=0.000$ between Social Awareness (SoA) andselfregulation (SR) explain the significantly positive and strong relationship. This means all the three components of emotional intelligence have strong relationship with each other. The increase in one will bring positive change in other and vice versa. The correlation between project success and self-awareness $(\mathrm{SA}),(\mathrm{r}=0.505, \mathrm{p}=0.000)$ explains the significantly positive and moderate relationship. Whereas the relationship between project success and self-regulation $(\mathrm{SR}),(\mathrm{r}=0.807, \mathrm{p}=0.000)$ explains the significantly positive and strong relationship. This implies that the self-awareness and regulated managers can play a vital role in the success of project. Project success has a positive but slight correlation $(\mathrm{r}=0.195, \mathrm{p}=0.000)$ with social awareness (SoA). This explains that the project natured complex workless allows the managers having social awareness about the team and more on technical or other aspects of the project resources.

\section{Regression analysis}

Regression analysis is conducted for estimating the relationships between a dependent variable and independent variables called as 'predictors' (Seber\& Lee, 2012). Table 5 indicates that the model (which includes both dependent and independent variables) is statistically significant $(\mathrm{F}=20.809, \mathrm{p}=.000]$, as the $\mathrm{p}$-value is less than 0.005 . Further, the $\mathrm{R}$-Square value $\left(\mathrm{R}^{2}=0.528\right.$ explains an overall variation in the dependent variable (project success) is $53 \%$ due to the predictors (emotional intelligence) while remaining variation in success may be due to other factors.

Table 5: Results of Regression analysis

\begin{tabular}{llllll}
\hline & \multicolumn{5}{c}{ Dependent Variable } \\
$\begin{array}{l}\text { Independent } \\
\text { Variable }\end{array}$ & & \multicolumn{5}{c}{ Project Success } \\
\hline $\begin{array}{l}\text { Emotional } \\
\text { Intelligence }\end{array}$ & Beta $(\beta)$ & T -Value & Sig. & F- value & Sig. \\
Constant & & & & & \\
SA & 2.015 & 7.488 & 0.000 & 20.809 & 0.000 \\
SR & 0.27 & 6.801 & 0.000 & & \\
SoA & 0.373 & 7.449 & 0.000 & & \\
& 0.062 & 1.371 & 0.188 & & \\
& & & & &
\end{tabular}

Predictor : $S A=$ Self Awareness,$S R=$ Self Regulation, $S o A=$ Social Awareness

Dependent Variable $=$ Project Success

Regression equations

$\mathrm{PS}=\alpha+\beta_{1}(\mathrm{SA})+\beta_{2}(\mathrm{SR})+\beta_{3}(\mathrm{SoA}) \ldots \ldots \ldots \ldots \ldots \ldots$. eq. 1

$\mathrm{PS}=2.015+0.27 \mathrm{SA}+0.373 \mathrm{SR}+0.062 \mathrm{SoA} \ldots \ldots . .$. eq. 2

The results (from eq. 2 ) show that 1 unit change in self-awareness (SA), will bring 0.27 units change in project success (PS). The value of $\beta_{1}=0.27,(t=6.801, p=0.000)$, as the $\mathrm{p}$-value is less than 0.05 so the null hypothesis is rejected, and alternative hypothesis 
is accepted. This implies a $27 \%$ variation in project success is due to self-awareness of project managers in construction companies of Peshawar. The results (from eq. 2) show that 1 unit change in self-regulation (SR), will bring 0.373 unit change in project success (PS). The value of $\beta_{2}=0.373$, $(\mathrm{t}=1.37, \mathrm{p}=0.000)$, as the $\mathrm{p}$-value is less than 0.05 so the null hypothesis is rejected, and alternative hypothesis is accepted. This implies a $37.3 \%$ variation in project success is due to self-regulation of project managers in construction companies of Peshawar. The results also show that 1 unit change in social awareness (SoA), will bring 0.062 unit change in project success (PS). The $\beta_{3}=0.060,(t=0.371$, $\mathrm{p}=0.188$ ), as $\mathrm{p}$-value is greater than the 0.05 so the null hypothesis is accepted. This means that social awareness has no or least statistically significant influence on project success in construction companies of Peshawar.

\section{Table 6: Findings of the Study}

\begin{tabular}{lll}
\hline $\mathrm{S} \mathrm{No}$ & Hypotheses & Decision \\
\hline $\mathrm{H}_{1}$ & $\begin{array}{l}\text { Emotional Intelligence (Self Awareness) is positively Hypothesis Accepted } \\
\text { related with the project success. }\end{array}$ \\
& $\begin{array}{l}\text { Emotional Intelligence (Self-Regulation) is positively Hypothesis Accepted } \\
\text { related with the project success. }\end{array}$ & \\
$\mathrm{H}_{2}$ & $\begin{array}{l}\text { Emotional Intelligence (social awareness) is positively Hypothesis Rejected } \\
\text { related with the project success. }\end{array}$ & \\
$\mathrm{H}_{3}$ &
\end{tabular}

Conclusion and Discussion

The main objective of this study was to identify the impact of independent variables i.e emotional intelligence on project success in construction industry of Peshawar Pakistan. Three attributes of emotional intelligence were used to check the impact on project success. The results of the study explain that the dimensions of emotional intelligence, self-awareness and self- regulation of project managers are showing positive and significant impact on the success of construction projects, while social awareness has insignificant impact which is the key finding of the study. All the attributes have an impact on project success in their own way. The highest rate of change $37 \%$ is found of self-regulation that explains the significance of managing self-emotions in any situation to achieve exceptional performance (Rahim \&Psenicka, 2002; Rahim\& Malik,2010; Serrat,2017). A total of 228 project managers responded out of 250 distributed questionnaires (91\% response rate) from the construction companies in Peshawar Pakistan. The responses exposed the significance of having self-awareness as well as self-regulation of project managers to come up with success. Moreover, social awareness of managers is showing negligible impact on the project success of construction companies in Peshawar. The reason of this finding can be the managers' more emphasis on tangible targets and materialist approach towards the project achievements which are mostly with short span of time and limited resources. The race of just finishing the 
project may not let the mangers to focus on understanding and respond to the needs of the team and that may deprive them to enjoy the impact of emotional intelligence on success. The results of the study are supported by the work of Mazur at al., (2014) and Muller \& Turner, (2007). Construction industry in Pakistan can take benefits from this research to improve the ratio of their successful projects by focusing on all the attributes of emotional intelligence as both have direct relation. The findings of the study strongly recommendadetailed study covering all dimensions of emotional intelligence (including empathy) as well as other work settings. Moreover, the managerial training of the project managers is suggested covering the contents of social awareness. The sample size of only 228 must be increased in future studies and for more than one city. More variables are directed to be included in the model in future studies to investigate the mediating or moderating effects of the variables.

\section{References}

Anantatmula, V. S. (2008). The role of technology in the project manager performance model. Project Management Journal, 39(1).

Boyatzis, R.E., (1982). The competent manager: A model for effective performance. John wiley and sons.

Brackett, M.A., Rivers, S.E. and Salovey, P., (2011). Emotional intelligence: Implication for personal, social, academic, and workplace success. Social and Personality Psychology Compass, 5(1), 88-103.

Cicmil, S. \& Hodgson D, (2006). New possibilities for project management theory: a critical engagement. Project management theory journal, 37(3),111-122.

Clarke, N., 2010. Emotional intelligence and its relationship to transformational leadership and key project manager competences. Project Management Journal. 41 (2), 5-20.

Fisher, C.D., 2003. Why do lay people believe that satisfaction and performance are correlated? Possible sources of a commonsense theory. J. Organ. Behav.24 (6), $753-777$.

Crawford, L.W. (2007). Developing the project management competence of individuals. In J. R. Turner (Ed.), Gower handbook of project management (4th ed., p. 678694). Aldershot, UK:Gower Publishing.

Fisher, E., 2011. What practitioners consider to be the skills and behaviors of an effective people project manager. Int. J. Proj. Manag. 29 (8), 994-1002.

Gehring, D. R. (2007). Applying traits theory of leadership to project management. Project Management Quarterly, 38(1), 44.

Goleman, D. (1998). Working with emotional intelligence. Bantam.

Joseph, D.L., \& Newman, D.A., (2010). Emotional intelligence: an integrative metaanalysis and cascading model. Journal of Applied Psychol. 95 (1), 54.

Jugdev, K., Müller, R., 2005. A retrospective look at our evolving understanding of project success. Proj. Manag. J. 36 (4), 19-31. What is job satisfaction? Organ. 
Behav. Hum. Perform. 4(4), 309-336.

Kulkarni. P.M., Janakiram, B. \& Kumar, D.N.S., 2009. Emotional intelligence and employee Performance as an indicator for promotion, 3 study of automobile industry in the city of Belgaum. Karnataka, 1ndia International Journal of Business and Management. 4(4),161.

Lee, G \& Xia, W, (2005). The ability of information system developed project teams to respond to business and technology changes: a study of flexibility measures. European journal of information system,14(1),483.

Landa, J.M.A., Lépez-Zafra, EL, Manes, M.P.B. and del Carmen Aguilar-Luzon, M., 2008. The relationship between emotional intelligence, occupational stress and health in nurses: a questionnaire survey. International Journal of Nursing Studies, 45(6),888-901.

Lindebaum, D., \& Jordan, P.J. (2014). When it can be good to feel bad and bad to feel good: exploring asymmetries in workplace emotional outcomes. Hum.Relat. 67, 1037-1050.

Mayer, J.D., Salovey, P., \& Caruso, D.R., (2008). Emotional intelligence: new ability or eclectic traits? Am. Psychol. 63 (6), 503.

Mazur, A., Pisarski, A., Chang, A., \& Ashkanasy, N.M., (2014). Rating defencemajor project success: the role of personal attributes and stakeholder relationships. Int. J. Proj. Manag. 32 (6), 944-957.

Mount, G., (2006). The Role of Emotional Intelligence in Developing International Business Capability: EI Provides Traction. Linking Emotional Intelligence and Performance at Work, 97-124.

Müller, R., \& Turner, R., (2010). Leadership competency profiles of successful project managers. Int. J. Proj. Manag. 28 (5), 437-448.

Müller, R., \& Jugdev, K., (2012). Critical success factors in projects: Pinto, Slevin, and Prescott— the elucidation of project success. Int. J. Manag. Projects Bus. 5 (4), 757775.

O'Boyle, E.H., Humphrey, R.H., Pollack, J.M., Hawver, T.H., \& Story, P.A.,(2011). The relation between emotional intelligence and job performance: a meta-analysis. J. Organ. Behav. 2, 788-818.

Papke-Shields, K.E., Beise,C. \& Quan, J., (2010). Do project manager practice what they preach, and does it matter to project success? International journal of project management,28(7), 45-54.

Peslak, A.R., (2005). Emotions and team projects and processes. Team Perform. Manag. $11(7 / 8), 251-262$.

Pinto, J.K., Slevin, D.P., 1987. Critical factors in successful project implementation. IEEE Trans. Eng. Manag. 1, 22-27.

Salovey, P., \& Mayer, J.D., (1990). Emotional intelligence. Imagination Cogn. Pers.9 (3), 185-211. 
Sy, T., Tram, S., \& O'Hara, L.A., (2006). Relation of employee and manager emotional intelligence to job satisfaction and performance. J. Vocat. Behav.68 (3), 461-473.

Toor, S.-u.-R., \& Ogunlana, S.O., 2010. Beyond the 'iron triangle': stakeholder perception of key performance indicators (KPIs) for large-scale public sector development projects. Int. J. Proj. Manag. 28 (3), 228-236.

Turner, J.R., \& Zolin, R., (2012). Modelling success on complex projects: multiple perspectives over multiple time frames. J. Project Manag. 87-99.

Von Glinow, M.A., Shapiro, D.L., \& Brett, J.M., (2004). Can we talk, and should we? Managing emotional conflict in multicultural teams. Acad. Manag. Rev. 29 (4), 578-592.

Yatim, F., Bredillet, C. N., \& Ruiz, P. (2009). Investigating the deployment of project management: A new perspective based on the concept of certication. International Journal of Managing Projects in Business, 2(3), 445-454.

Wang, X., \& Huang, J., (2006). The relationships between key stakeholders' project performance and project success: perceptions of Chinese construction supervising engineers. Int. J. Proj. Manag. 24 (3), 253-260.

Siddiq, A., Baloch, Q. B., Nadeem, A., Ahmad, S., \& Jan, M. F. (2015). Emotional Intelligence: A Driving Force towards Organizational Development. Journal of Management Research (JMR), 1(2), 86-104.

Rahim, A. ,Psenicka, C., Polychroniou, P., Zhao, J. H., Yu, C. S., Anita Chan, K., ... \&Ferdausy, S. (2002). A model of emotional intelligence and conflict management strategies: A study in seven countries. The International journal of organizational analysis, 10(4), 302-326.

Mullin, M., Smith, M. D., \& McNamara, D. E. (2019). Paying to save the beach: effects of local finance decisions on coastal management. Climatic Change, 152(2), 275289.

Joseph, N., \&Marnewick, C. (2018). Investing in project management certification: Do organisations get their money's worth?. Information Technology and Management, 19(1), 51-74.

Luong, T. T., Sivarajah, U., \&Weerakkody, V. (2019). Do Agile Managed Information Systems Projects Fail Due to a Lack of Emotional Intelligence?. Information Systems Frontiers, 1-19.

Oke, A., Aigbavboa, C., Ngcobo, N., \&Sepuru, M. (2017). Challenges of Emotional Intelligence among Construction Stakeholders. In ICCREM 2017, 33-40.

Rezvani, A., Chang, A., Wiewiora, A., Ashkanasy, N. M., Jordan, P. J., \&Zolin, R. (2016). Manager emotional intelligence and project success: The mediating role of job satisfaction and trust. International Journal of Project Management, 34(7), 1112-1122.

Zhang, L., \& Fan, W. (2013). Improving performance of construction projects. Engineering, Construction and Architectural Management. 
Rahim, S. H., \& Malik, M. I. (2010). Emotional intelligence \& organizational performance:(A case study of banking sector in Pakistan). International Journal of Business and Management, 5(10), 191.

Mohammad, N., Akhtar, S., Ur Rahman, M. K., \& Haleem, F. (2018). The moderating effect of age, gender and educational level on relationship between emotional intelligence and job satisfaction: An analysis of the banking sector of Pakistan. Middle East Journal of Business, 55(6093), 1-9.

Shahzad, K., Sarmad, M., Abbas, M., \& Khan, M. A. (2011). Impact of Emotional Intelligence (EI) on employees performance in telecom sector of Pakistan. African Journal of Business Management, 5(4), 1225-1231.

Wong, C.S., \& Law, K.S. (2002). The effects of leader and follower emotional intelligence on performance and attitude: An exploratory study. Leadership Quarterly, 13, 243-274. https://doi.org/10.1016/ S1048-9843(02)00099-1

Shenhar, A. J., Tishler, A., Dvir, D., Lipovetsky, S., \&Lechler, T. (2002). Refining the search for project success factors: a multivariate, typological approach. R\&d Management, 32(2), 111-126.

Seber, G. A., \& Lee, A. J. (2012). Linear regression analysis (Vol. 329). John Wiley \& Sons.

Serrat, O. (2017). Understanding and developing emotional intelligence. In Knowledge solutions (329-339). Springer, Singapore. 